\title{
Markedsføring på ville veier
}

\author{
De siste årene er markedsføringen av legetjenester blitt mer aggressiv, og den er ofte i strid \\ med Legeforeningens etiske regler.
}

\section{Trond Markestad}

trond.markestad@helse-bergen.no

Rådet for legeetikk

Den norske legeforening

Postboks 1152 Sentrum

0107 Oslo

Rådet for legeetikk har i de senere år sett at det er blitt en mer aggressiv markedsføring av legetjenester. Ofte er den i strid med kapittel III i Legeforeningens etiske regler, der det stilles strenge krav til nøkternhet og objektivitet (1). I kapittel III $\S 1$ heter det: «Avertissement og annen informasjon om legetjenester kan bare inneholde opplysninger om virksomhetens lokalisering, åpningstid og administrasjon, praksistype, spesialitet og tittel, diagnostiske og terapeutiske metoder og priser.»

I kapitlet utdypes begrensningene ved at det presiseres at avertissementer bare må reflektere medisinsk allment aksepterte og/eller vitenskapelig dokumenterte indikasjonsstillinger og/eller metoder. Videre at annonser ikke må være utformet slik at de kan skape angst, fordommer eller urealistiske forventninger. De må heller ikke si noe om forventet resultat, tjenestens kvalitet eller gi inntrykk av at pasientens eller andres helse kan settes i fare hvis vedkommende ikke benytter seg av tjenesten. Spesialitet kan oppgis, men det er ikke tillatt å avertere med at man er spesialist på en bestemt sykdom. Navnet på (d)en ansvarlig(e) lege skal stå i annonsen.
Rådet for legeetikk har tidligere skrevet om ett avertissement som strider mot kravet om aksepterte metoder (2) og om ett som strider mot kravet om nøkternhet og objektivitet (3). Rådet har også uttalt seg kritisk mot flere andre avertissementer. Denne kritikken er gjengitt i rådets årsmeldinger (4). Noen eksempler: Tre privat helseforetak markedsførte seg som «ledende» innen sitt fagområde, noe som strider mot kravet om ikke å uttale seg om tjenestens kvalitet (4, årsmeldingen 2007, 2008 og 2009). I en brosjyre ble det anbefalt generell ultralydscreening hvert annet år fra 40 års alder for at man skulle oppdage sykdom (4, årsmeldingen 2009). Og en annonse med tittelen Vil du vite om du er i risikogruppen for hjerteinfarkt? (4, årsmeldingen 2009) ble det argumentert for å bestemme kalsiumskår - uten at slike metoder er alminnelig akseptert som screeningmetoder. Rådet mener at slike annonser er i strid med kravet om ikke å skape helseangst eller urealistiske forventninger.

Nylig har rådet kommet med kritikk av en helsides avisannonse for kosmetisk kirurgi. Blikkfanget var et bilde av en slank og smilende bikinikledd kvinne og to smilende slanke barn. Overskriften i store bokstaver var Din kropp - ditt selvbilde. Videre het det i teksten: «Ditt selvbilde er sterkt knyttet til kroppen din.» Annonsen var i strid med flere av punktene i kapittel III i etikkreglene, blant annet den om at man ikke må skape fordommer.

Noen av annonsene kommer fra store private helseforetak med flere avdelinger og bærer preg av å være utarbeidet av ledelsen i samarbeid med et reklamebyrå. Rådet mener at leger som arbeider på heltid eller deltid i slike helseforetak har et klart ansvar for å bidra til at markedsføringen skjer $\mathrm{i}$ tråd med bestemmelsene $\mathrm{i}$ etiske regler for leger.

Rådet vil presisere at det ikke er i strid med etikkreglene å markedsføre slike tjenester, forutsatt at det ikke argumenteres for udokumenterte helsegevinster og annonsen ikke er utformet slik at den skaper fordommer og helseangst. Rådet hadde for eksempel ikke innvendinger mot en rubrikkannonse for generell ultralydscreening der det kun ble oppgitt at dette var et tilbud, foruten pris og legens navn (4, årsmeldingen 2008).

\section{Oppgitte interessekonflikter: Ingen}

\section{Litteratur}

1. Etiske regler for leger. www.legeforeningen.no/id/ 485.1 (14.5.2010)

2. Markestad T. Bruk av kvantemedisin i strid med etiske regler for leger. Tidsskr Nor Legeforen 2009; 129: 1907

3. Markestad T. Annonsering av forebyggende helseprogram. Tidsskr Nor Legeforæn 2006; 126: 2852-3.

4. Årsmeldinger for rådet for legeetikk. www.legeforeningen.no/id/158877.0 (14.5.2010).

Manuskriptet ble mottatt 25.4. 2010 og godkjent 14.5. 2010. Medisinsk redaktør Petter Gjersvik.

\section{Medisinsk etikk}

Etiske refleksjoner er en viktig del av legers virksomhet. I spalten Medisinsk etikk publiseres artikler om etiske spørsmål knyttet til klinisk praksis, pasientbehandling. helseforvaltning og medisinsk forskning. Artiklenes lengde og form vil variere. 